\title{
SOME NEW OPERATOR INEQUALITIES
}

\section{Mohammad Sababheh, Hamid Reza Moradi And IbRahim Halil Gümüş}

Abstract. In this article, we present some new inequalities for positive linear mappings that can be viewed as super multiplicative inequalities. As applications, we deduce some numerical radius inequalities. Then several inequalities for the numerical radius are presented with the aid of convex functions.

Mathematics subject classification (2010): 47A63, 47A30, 15A60, 47A12.

Keywords and phrases: Operator inequality, norm inequality, numerical radius, convex function, positive linear map.

\section{REFERENCES}

[1] A. ABU-OMAR AND F. KitTANEh, Upper and lower bounds for the numerical radius with an application to involution operators, Rocky Mountain J. Math. 45(4) (2015), 1055-1065.

[2] J. Aujla AND F. Silva, Weak majorization inequalities and convex functions, Linear Algebra Appl. 369 (2003), 217-233.

[3] R. Bhatia And C. Davis, A better bound on the variance, Amer. Math. Monthly. 107 (2000), 353357.

[4] R. Bhatia And R. Sharma, Some inequalities for positive linear maps, Linear Algebra Appl. 436 (2012), 1562-1571.

[5] M.D. CHOI, A Schwarz inequality for positive linear maps on $C^{*}$-algebras, Illinois J. Math. 18 (1974), $565-574$.

[6] S. S. DRAGomiR, Some inequalities for the norm and the numerical radius of linear operators in Hilbert spaces, Tamkang J. Math. 39 (2008), 1-7.

[7] K. Davidson And S. C. Power, Best approximation in $C^{*}$-algebras, J. Reine Angew. Math. 368 (1986), 43-62.

[8] P. R. Halmos, A Hilbert Space Problem Book, 2nd ed., Springer, New York, 1982.

[9] F. KitTANEH, Norm inequalities for sums and differences of positive operators, Linear Algebra Appl. 383 (2004), 85-91.

[10] F. Kittaneh, Numerical radius inequalities for Hilbert space operators, Studia Math. 168 (2005), $73-80$.

[11] J. MiĆIĆ, J. PEČARIĆ AND Y. SEO, Complementary inequalities to inequalities of Jensen and Ando based on the Mond-Pečarić method, Linear Algebra Appl. 318 (2000), 87-108.

[12] H. R. Moradi AND M. SABABheH, More accurate numerical radius inequalities (II), Linear Multilinear Algebra., https://doi.org/10.1080/03081087.2019.1703886.

[13] V. Paulsen, Completely bounded maps and operator algebras, Cambridge Studies in Advanced Mathematics 78, Cambridge University Press, Cambridge, 2002.

[14] J. PEČARIĆ AND J. MIĆIĆ, Some functions reversing the order of positive operators, Linear Algebra Appl. 396 (2005), 175-187.

[15] M. SABABHeH AND H. R. Moradi, More accurate numerical radius inequalities (I), Linear Multilinear Algebra., https://doi .org/10.1080/03081087.2019.1651815.

[16] M. Sababheh, H.R. Moradi AND S. Furuichi, Operator inequalities via geometric convexity, Math. Ineq. App. 22 (2019), 1215-1231. 